\title{
Teknik Konservasi Tanah serta Implementasinya pada Lahan Terdegradasi Dalam Kawasan Hutan
}

\author{
(Soil Conservation Technique and Its Implementation in the
} Degraded Land of Forest Regions)

\author{
Wahyudi \\ Fakultas Pertanian, Jurusan Kehutanan, Universitas Palangka Raya \\ e-mail: wahyudi888@yahoo.com
}

\begin{abstract}
Large of degraded forest areas in Indonesia namely 19.5 million ha and its rate start from 1.8 to 2.84 million ha years1. Initially in the form of virgin forests, they were degraded become low potential forest, scrub, bush, grass land to critical land. The critical land is very dangerous for natural resources establishment because happened the high erosion and menacing flood. The solutions to minimize the environmental damage in the critical land are developing the soil conservation technique in the sites. This research was aimed to collect and analyze some soil conservation techniques and its implementation in the degraded land of forest regions. The research was conducted with literature and fields study in the PT Gunung Meranti areas, Kapuas District, Central Kalimantan Province. Some soil conservation techniques that applied in the degraded land of forest regions are wet masonry, stone terrace works, gabion works, log retaining works,log grib works,bamboo and wicker terrace, soil bag terrace works and straw mat terrace works. To support the civil and vegetation soil conservation technique, commonly using the water channels as sod water channel works, stone water channel works, soil bag water channel works and catchment pipe culvert.
\end{abstract}

Keywords: Critical land, erosion, soil conservation technique

\section{PENDAHULUAN}

\section{Latar Belakang}

Pembukaan dan pemanfaatan hutan alam yang berorientasi ekonomi dilakukan sejak tahun 70-an berdasarkan UU No.1/1967 tentang Penanaman Modal Asing, UU No.5/67 tentang Kehutanan dan UU No.6/1968 tentang Penanaman Modal Dalam Negeri. Beberapa tahun setelah dibukanya keran pengusahaan hutan dalam bentuk Hak Pengusahaan Hutan (HPH), laju kerusakan hutan tropika menunjukkan angka yang semakin meningkat dari tahun ke tahun. Saat ini tercatat laju kerusakan hutan di Indonesia sebesar 1,8 juta ha/th (1985-1997) dan meningkat menjadi 2,84 juta ha/th (19972000) (Balitbanghut 2008). Kawasan hutan yang terdegradasi akan berubah menjadi belukar (scrubs), semak (bush), padang alang-alang (Imperat cylindrica) dan apabila kerusakan terus berlanjut, seperti kebakaran hutan dan lahan, akan terbentuk lahan kritis (critical land), yaitu hamparan lahan yang mengalami penurunan daya dukung lahan sehingga tidak sanggup lagi menopang pertumbuhan tanaman serta rawan terhadap banjir dan erosi (Wahyudi 2013).

Salah satu penyebab lahan kritis adalah adanya aktifitas yang melebihi kemampuan lahan, seperti kegiatan pengusahaan hutan yang melanggar ketentuan, penebangan liar, perladangan berpindah, perambahan lahan dan kebakaran hutan dan lahan. Disamping itu adanya kegiatan konversi 
kawasan hutan menjadi areal pertambangan, perkebunan, pemukiman dan lain-lain yang kurang terencana dengan baik juga mempercepat terbentuknya lahan kritis (Dephut 1996, Mori 2001, Wahyudi 2014).

Kebiasaan masyarakat, khususnya di Kalimantan, melakukan pola pertanian secara berpindahpindah (shifted cultication). Tradisi ini dilakukan mengikuti kondisi tanah marginal yang tidak memungkinkan digunakan secara-terus menerus untuk bercocok tanam. Diperlukan masa bera sekitar 5-10 tahun untuk dapat kembali pada areal semula. Namun seiring dengan pesatnya pertambahan penduduk, baik melalui kelahiran (natalitas) maupun pendatang (migrasi), masa bera yang dipergunakan kini semakin pendek, yaitu sekitar 2-5 tahun (Lahjie2004) atau membuka areal baru dengan membabat hutan alam.

\section{PENGERTIAN}

\section{Kawasan hutan dan Lahan}

Hutan adalah suatu kesatuan ekosistem berupa hamparan lahan berisi sumber daya alam hayati yang didominasi pepohonan dalam persekutuan alam lingkungan, yang satu dengan lainnya tidak dapat dipisahkan (UU No.41/1999). Sedangkan kawasan hutan adalah wilayah tertentu yang ditunjuk dan atau ditetapkan oleh pemerintah untuk dipertahankan keberadaannya sebagai hutan tetap. Pengertian lahan lebih terarah pada hamparan tanah yang terdapat dipermukaan bumi. Beberapa sumber membedakan antara kawasan hutan dan lahan. Kawasan hutan adalah kawasan yang telah ditetapkan pemerintah sebagai hutan tetap. Sedangkan lahan adalah kawasan diluar kawasan hutan. Kegiatan penanaman dalam kawasan hutan disebut reboisasi sedangkan penanaman di luar kawasan hutan atau pada lahan disebut penghijauan (Dephut 1996). Namun demikian, baik di dalam kawasan hutan maupun di luar kawasan hutan dapat ditumbuhi vegetasi, terutama pepohonan dalam persekutuan alam lingkungan, yang satu dengan lainnya tidak dapat dipisahkan, yaitu berupa hutan.

Kerusakan dapat diartikan sebagai penurunan atau hilangnya fungsi dari suatu obyek tersebut. Kerusakan hutan dan lahan berarti penurunan atau hilangnya fungsi hutan dan lahan serta daya dukungnya terhadap lingkungan. Kerusakan hutan dapat berbentuk penurunan potensi hutan, perubahan penutupan vegetasi, misalnya dari hutan primer menjadi semak belukar atau padang alang-alang, dan kerusakan pada sifat fisik, kimia dan biologinya. 


\section{Erosi Tanah}

Erosi (erosion) adalah proses hilangnya atau terkikisnya tanah atau bangun tanah dari suatu tempat ke tempat lain yang diangkut (disebabkan) oleh air atau angin. Menurut Siswomartono(1989), erosi adalah pengikisan permukaan tanah oleh air yang mengalir, angin, es atau perantara-perantara geologi lainnya, termasuk proses rayapan gravitasi. Erosi juga dapat diartikan sebagai pemisahan atau pemindahan tanah atau fragmen-fragmen batuan oleh air, angin, es atau gaya berat.

Bentuk-bentuk erosi meliputi erosi karena aktivitas (sheet erosion, rill erosion, gully erosion and stream bank erosion) serta erosi normal (normal erosion). Erosi tanah dipengaruhi oleh erodibilitas dan karakteristik tanah. Erodibilitas meliputi proses pelepasan, pengangkutan dan permeabilitas tanah atau kemampuan tanah untuk menyerap dan melalukan air. Sedangkan karakteristik tanah dipengaruhi oleh tekstur tanah, struktur tanah, bahan organik dan infiltrasi tanah.

\section{Lahan Kritis}

Lahan kritis (critical land) adalah lahan yang karena tidak sesuainya penggunaan lahan dengan kemampuannya telah mengalami atau dalam proses kerusakan fisik, kimia dan biologi, yang akhirnya membahayakan fungsi hidrologi, orologi, produksi pertanian, pemukiman dan kehidupan sosial ekonomi. Berdasarkan Keputusan Dirjen Reboisasi dan Rehabilitasi Lahan No.41/Kpts/V/1998, lahan kritis adalah lahan yang telah mengalami kerusakan sehingga kehilangan atau berkurang fungsinya sampai batas yang ditentukan atau diharapkan. Lahan kritis dapat pula diartikan sebagai lahan yang semula baik untuk pertanian kemudian berubah menjadi tidak cocok setelah adanya kegiatan di lahan tersebut. Lahan kritis dapat pula ditinjau dari aspek lain, misalnya lahan yang mempunyai penutupan vegetasi kurang dari $25 \%$, lahan dengan topografi $>45 \%$ atau lahan yangs telah terkena erosi, misalnya erosi parit (gully erosion).

Menurut Siswomartono (1989), lahan kritisadalah suatu daerah penghasil sedimen yang tererosi berat, yang memerlukan pengelolaan khusus untuk menetapkan dan memelihara vegetasi dalam rangka menstabilkan kondisi tanah. Sedangkan jangkauan kritis (critical reach) adalah tempat dalam aliran penerima di bawah suatu titik pengeluaran dimana dicapai kadar oksigen terlarut paling rendah dan saat mulainya pemulihan. 


\section{Konservasi}

Kata "konservasi" mengandung makna pengawetan atau usaha menuju kearah perbaikan. Menurut Dephut (1985 dan 1990), konservasi berarti upaya pengelolaan sumber daya alam secara bijaksana dengan berpedoman pada azas kelestarian. Berdasarkan Surat Keputusan Bersama Menteri Dalam Negeri, Menteri Kehutanan dan Menteri Pekerjaan Umum No.19/1984, No. 059/Kpts-II/84 dan No.124/Kpts/84, Konservasi tanah adalah upaya untuk mempertahankan atau memperbaiki daya guna lahan termasuk kesuburan tanah dengan cara pembuatan bangunan teknik sipil disamping tanaman (vegetatif), agar tidak terjadi kerusakan tanah dan kemunduran daya guna dan produktifitas lahan.

Menurut Siswomartono (1989), konservasi adalah perlindungan, perbaikan dan pemakaian sumber daya alam menurut prinsip-prinsip yang akan menjamin keuntungan ekonomi atau sosial yang tertinggi secara lestari. Konservasi standar adalah standar untuk berbagai type tanah dan pemakaian tanah, meliputi kriteria, teknik dan metode-metode untuk pengendalian erosi dan sedimen yang disebabkan oleh aktivitas penggunaan tanah. Sedangkan Pengolahan Konservasi adalah setiap sistem pengolahan tanah yang mengurangi kehilangan tanah atau air dibanding pengolahan tanah yang lain, yang tidak mengindahkan kaidah konservasi.Konservasi tanah dan air mengandung pengertian bagaimana kita menggunakan tanah agar dapat memberi manfaat yang optimum bagi kepentingan umat manusia dalam jangka waktu berkelanjutan. Kegiatan konservasi tanah meliputi pengendalian erosi, banjir, pengaturan pemanfaatan air, peningkatan daya guna lahan, peningkatan produksi dan pendapatan petani termasuk peningkatan peran serta masyarakat yang terpadudan kegiatan pengamanannya (Wahyudi 2014).

Kegiatan konservasi tanah diutamakan menggunakan metode mekanis (teknik sipil), seperti pembuatan teras sering, bangunan pengendali, bangunan penahan sedimen dan erosi dan lain-lain (Masaki 1995). Tahapan pelaksanaan kegiatan konservasi meliputi perencanaan, pelaksanaan, bimbingan teknis pelaksanaan, pemeliharaan, monitoring dan penyuluhan pada masyarakat.

\section{TEKNIK DAN IMPLEMENTASI KONSERVASI TANAH DALAM KAWASAN HUTAN}

\section{Konservasi pada Kawasan Hutan}

Teknik konservasi pada lahan berhutan dilakukan dengan penerapan manajemen pengelolaan hutan yang baik dan terencana. Pada kawasan hutan lindung dan kawasan hutan konservasi, upaya konservasi tanah dan air hanya menjaga lingkungan dari kerusakan, karenapada kedua kawasan ini 
tidak diperkenankan melakukan penebangan pohon. Pada kawasan hutan produksi, upaya konservasi dilakukan pada 3 areal, yaitu areal produktif sebagai tempat dilakukan kegiatan eksploitasi hutan (penebangan pohon dan penarikan kayu); kawasan tidak efektif untuk produksi seperti lokasi perkantoran, perumahan, camp, sarana dan prasarana, lokasi penelitian, lokasi sumber benih atau areal sumberdaya genetik, kebun bibit, persemaian dan tanah kosong serta kawasan perlindungan sepertiareal areal plasma nutfah,sungai dan mata air, buffer zone, koridor satwa dan areal yang mempunyai kelerengan $>40 \%$.

\section{Konservasi pada Lahan Terdegradasi}

Pada lahan yang tidak berhutan atau lahan kritis, metode konservasi tanah yang dipakai dapat menggunakan bangunan teknik sipil atau cara mekanis dan teknik vegetatif. Teknik sipil dilakukan dengan pembuatan teras sering, bangunan penahan, bangunan drainase, penutupan dan lain-lain. Sedangkan teknik vegetatif dilakukan dengan menggunakan tumbuhan atau tanaman. Pola tanam yang digunakan dapat berbentuk penanaman dalam strip (strip cropping), pola tanam ganda atau majemuk (multiple cropping), sistem pertanian hutan (agroforestry), pemanfaatan sisa tanaman (residual management) dan penanaman pada saluran pembuangan (grassed water ways). Teknik konservasi juga dapat dilakukan dengan kombinasi bangunan teknik sipil dan cara vegetatif. Pada lahan sangat kritis yang berada di daerah kelerengan curam, teknik sipil didahulukan sebelum penanaman dilakukan.

\section{Implementasi Teknik Konservasi Tanah pada Kawasan Hutan}

Konservasi tanah pada areal produktif dilakukan pada areal bekas tebangan, seperti bekas jalan sarad dan cabang, bekas tempat pengumpulan kayu (TPn), bekas tempat penimbunan kayu (TPK) serta tempat-tempat kosong lainnya. Tujuan utama kegiatan konservasi di sini adalah menutup permukaan tanah yang terbuka akibat kegiatan eksploitasi hutan untuk menekan terjadinya erosi serta menanam dengan jenis komersial untuk meningkatkan produktivitas kawasan hutan.

Di PT Gunung Meranti, Kalimantan Tengah, bekas jalan sarad dibuat teras sering menggunakan stek batang sungkai (Peronema canescens). Pada tahun pertama kegiatan ini mampu menurunkan erosi tanah hingga 66,2\% dan pada tahun kedua menurunkan erosi sebesar 27,6\%. Setelah stek batang sungkai tumbuh menjadi pohon, maka kejadian erosi telah mendekati kondisi awal. Pada saat itu vegetasi penutup lahan selain tanaman sungkai, juga tumbuh alami berbagai herba dan tumbuhan bawah (PT GM, 2011). 


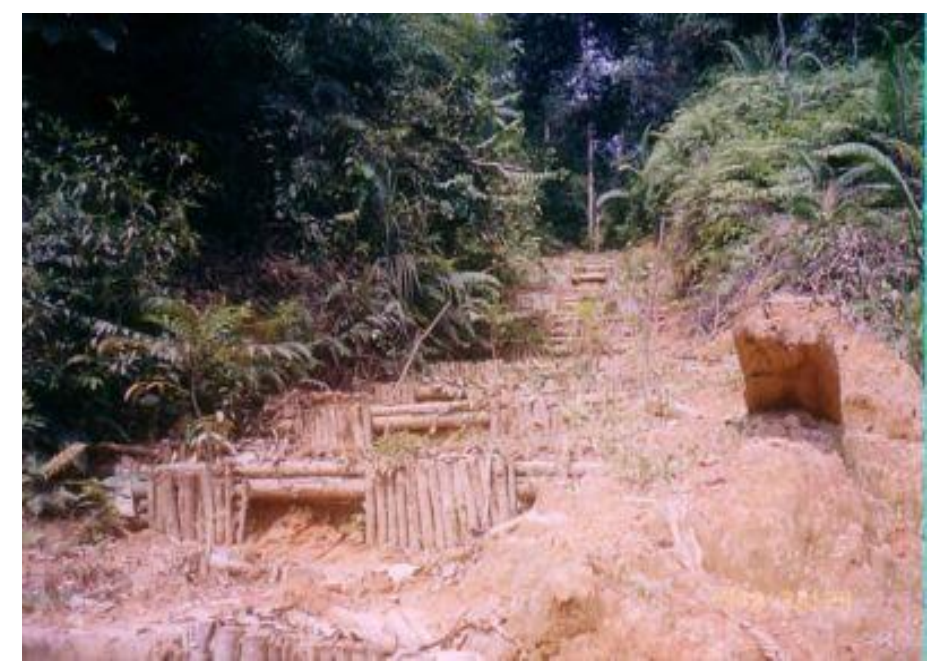

Gambar 1. Konservasi tanah pada bekas jalan sarad di kawasan hutan dengan kemiringan 10\%.

Untuk melakukan perbaikan (konservasi) lahan kritis, terutama yang berada pada daerah yang mempunyai kelerengan, bangunan teknik sipil sebaiknya didahulukan dibuat, menyusul teknik konservasi vegetatif, yaitu dengan melakukan penanaman jenis cepat tumbuh (fast growing species), tanaman penutup (cover cropt) baik jenis asli (native species) maupun luar (exotic species), dan atau memelihara pertumbuhan alam (natural regeneration). Perpaduan kedua teknik tersebut sangat tepat diterapkan untuk merehabiitasi lahan lritis. Beberapa bentuk tindakan konservasi tersebut adalah (Masaki, 1995):

\section{Teras Tembok (Wet Masory)}

Pembuatan bangunan teras tembok atau tembok penahan (wet masonry) bertujuan untuk menghambat aliran air dan erosi, yang dibuat dari konstruksi beton. Pada bagian saluran dibuat sodetan untuk aliran air yang dikombinasi tindakan konservasi vegetatif, seperti penanaman rumput dan cover cropt lain.

Konstruksi ini dipilih apabila terdapat tekanan yang cukup besar dari bagian belakang, yang berasal dari material tanah maupun volume air yang akan datang dan menginginkan tingkat kekokohan yang tinggi pada bagian atas bangunan, misalnya akibat batuan yang lonsor dan lain-lain.

Persyaratan teknis konstruksi tembok penahan adalah:

a. Tinggi konstruksi sampai 3 meter dengan kemiringan mengikuti kelerengan bukit

b. Tempat pembuangan air dibuat 1 buah per $3 \mathrm{~m} 2$ supaya tidak terjadi genangan air pada bagian belakang konstruksi 
c. Pada bagian belakang dinding beton diberi kerikil untuk meningkatkan permeabilitas tanah, sehingga tidak terjadi genangan saat hujan lebat

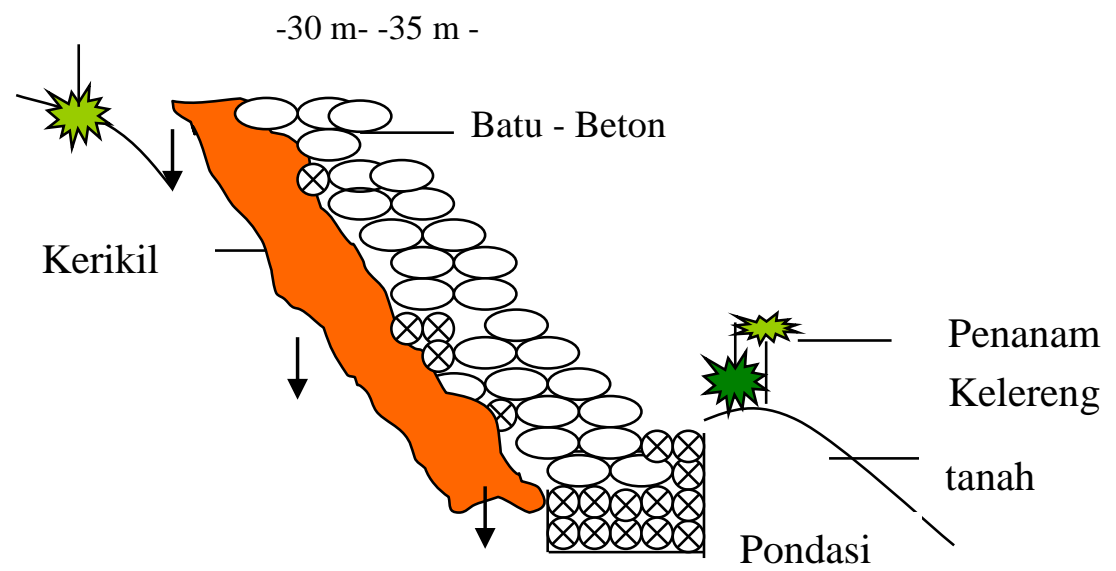

- 50 m- Wahyudi, 2014

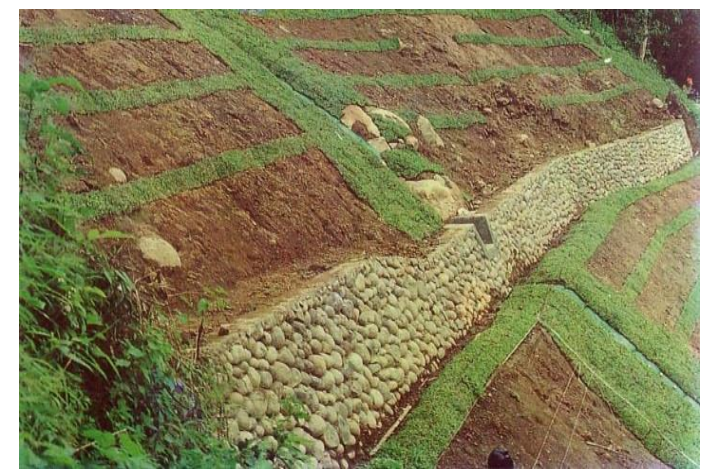

Gambar 2. Ilustrasi dan contoh bangunan tembok penahan (wet masonry)

\section{Teras Batu (Stone Terrace Works)}

Teras batu atau batu penahan (stone terrace works), pada prinsipnya sama denganteras tembok atau tembok penahan. Pada batu penahan biaya yang digunakan lebih sedikit, namun tingkat kekuatannya lebih rendah dibanding tembok penahan. Pada teknik ini dapat ditambahkan dengan penanaman rumput, bambu atau tanaman keras karena dapat membantu menjaga kestabilan permukaan tanah. 


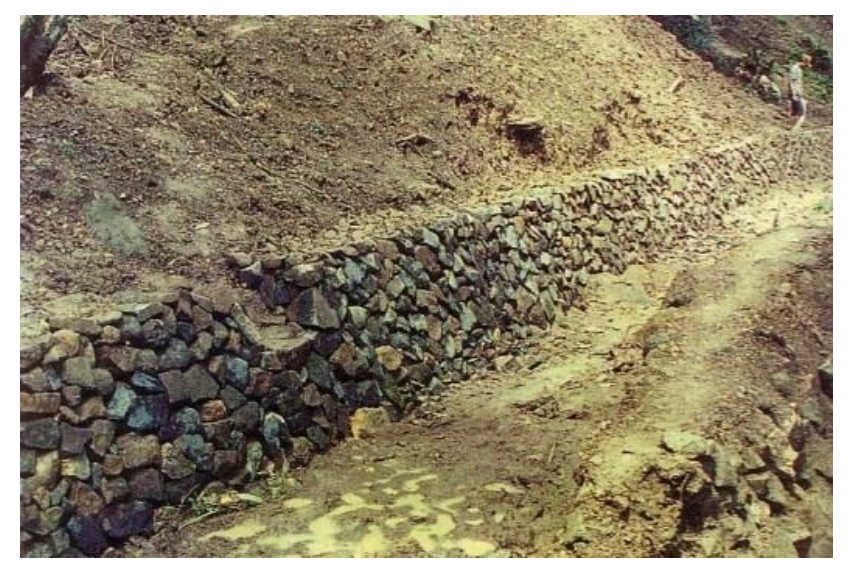

Gambar 3. Contoh bangunan batu penahan

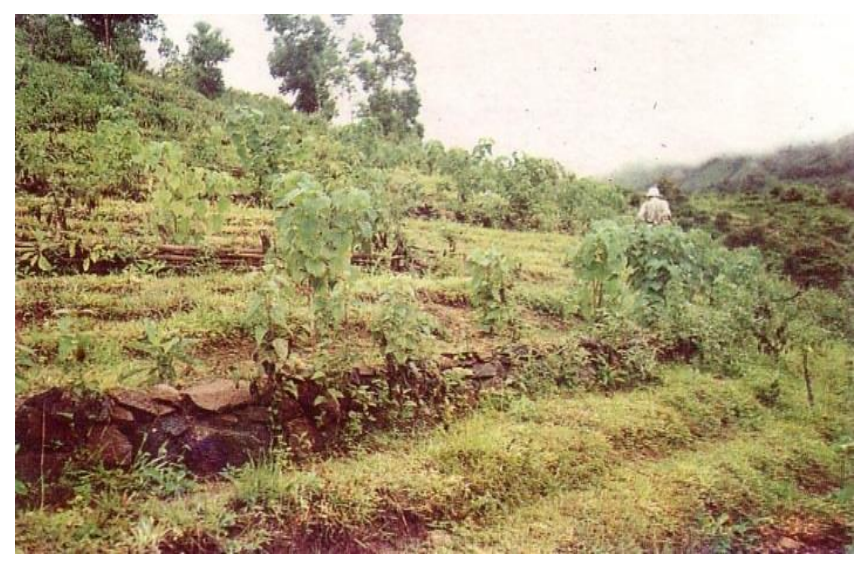

Gambar 4. Contoh bangunan batu penahan dengan kombinasi vegetasi yang mulai berfungsi kembali untuk menata lingkungan

\section{Pemasangan Kawat Bronjong (Gabion Works)}

Untuk memperkuat konstruksi teras batu, dapat ditambahkan kawat bronjong yang dapat mengikat material batu satu dengan lainnya. Penggunaan kawat bronjong mutlak dilakukan apabila teras batu dibuat bertingkat. Persyaratan teknis antara lain:

a. Tinggi maksimal 2 meter dengan pondasi berupa tancapan kayu yang keras.

b. Menggunakan batu yang keras (tidak mudah lapuk) dan lebih besar dari mata kawat

c. Susunan batu saling mengunci antara yang besar dan kecil sehingga memperkecil rongga yang dapat mengakibatkan bergerak/turunnya pondasi.

d. Segera diikuti konservasi secara vegetatif dengan jenis yang memiliki perakaran kuat dan dalam. 


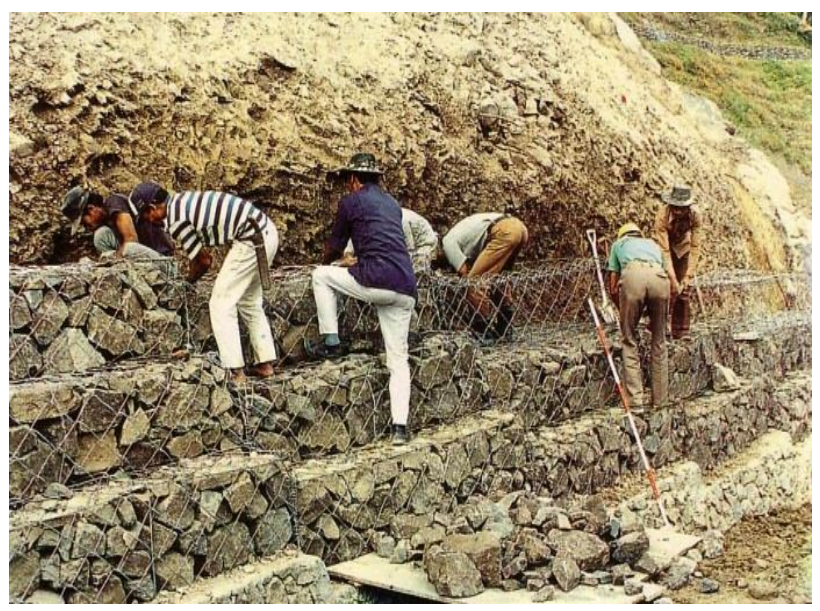

Gambar 5. Penggunaan kawat bronjong pada teras batu bertingkat

\section{Teras Kayu (Log Retaining Works)}

Teras kayu disebut juga bangunan kayu penahan (Log Retaining Works), digunakan untuk menahan longsor dalam skala kecil atau tekanan yang tidak besar di belakang dinding penahan. Bangunan ini relatif berumur pendek, oleh karena itu penanaman vegetasi harus segera dilakukan untuk menggantikan fungsi teknik sipilnya, dengan menggunakan fast growing spesies. Persyarat teknis kayu penahan ini adalah:

a. Tinggi bangunan sampai dengan 1 meter dengan pondasi kayu keras.

b. Bila terdapat rongga atau lubang, ditutup dengan rerumputan, cabang, ranting dan lainnya agar tanah tidak hanyut dan mempertahankan kestabilan tanah timbunan.

c. Sangat tepat digunakan pada daerah yang masih banyak tersedia bahan baku gelondongan kayu.

d. Segera dilakukan konservasi vegetatif dengan jenis cepat tumbuh. 


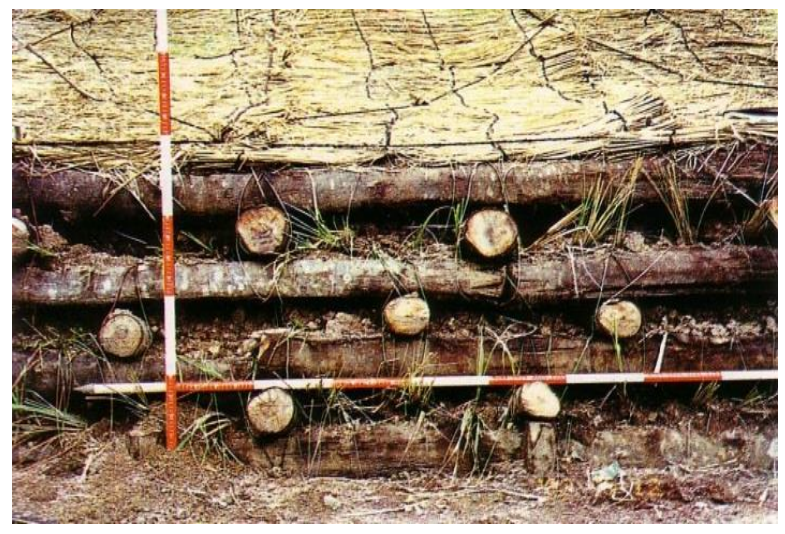

Gambar 6. Contoh bangunan teknis (konstruksi) kayu penahan

\section{Teras Kotak (Log Grib Works)}

Pekerjaan teras kotak dilakukan untuk mencegah tumbuhan air hujan dan menahan aliran permukaan sehingga bahaya erosi dan longsor dapat ditekan seminimal mungkin.

Persyarat teknis yang diperlukan adalah:

a. Permukaan tanah diratakan sesuai kelerengan.

b. Pembuatan kotak persegi dilakukan dengan kayu bulat kecil yang diikat satu dengan lainnya membentuk luasan sekitar 2-5 m2. Pekerjaan dimulai dari bawah ke atas.

c. Penutupan kotak dengan kantong-kantong tanah.

d. Apabila terdapat saluran air, dibuatkan gorong-gorong

e. Segera dilakukan penanaman (konservasi vegetatif)
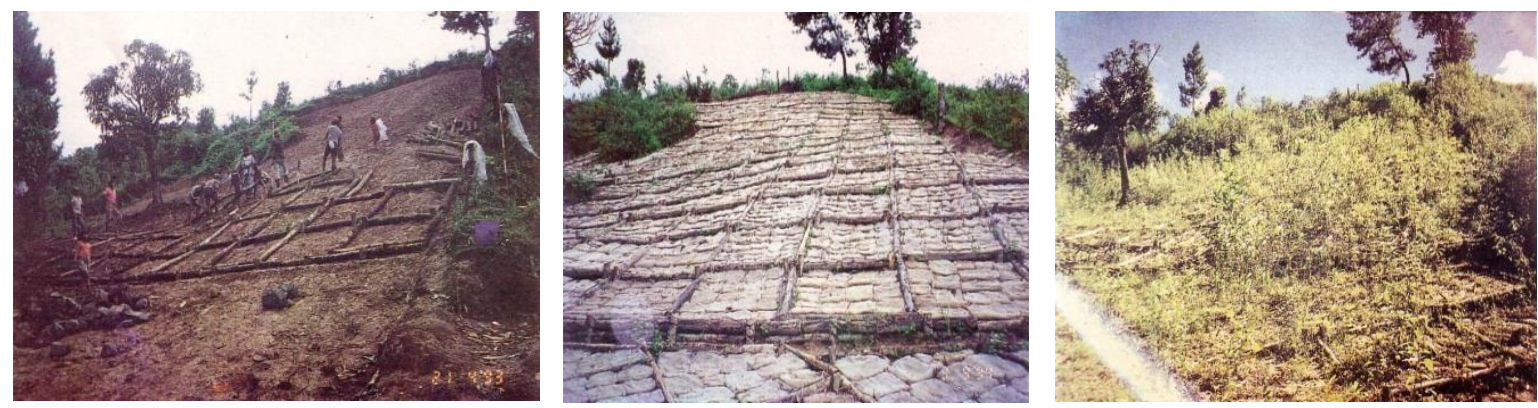

Gambar 7. Rangkaian pembuatan dan hasil dari teras kotak pada lahan kritis 


\section{Teras Bambu dan Ranting (Bamboo and Wicker Terrace Works)}

Pada prinsipnya teras bambu dan ranting mirip dengan kayu penahan (Log Retaining Works). Perbedaan hanya terletak pada material yang digunakan serta cara pembuatan. Teras bambu dibuat dengan menganyam bambu pada kayu keras yang berfungsi sebagai patok. Sedangkan teras ranting dibuat dengan memanfaatkan sisa-sisa batang dan ranting pohon. Baik teras bambu maupun ranting, segera diikuti dengan konservasi vegetatif, karena usia bambu maupun kayu relatif pendek.

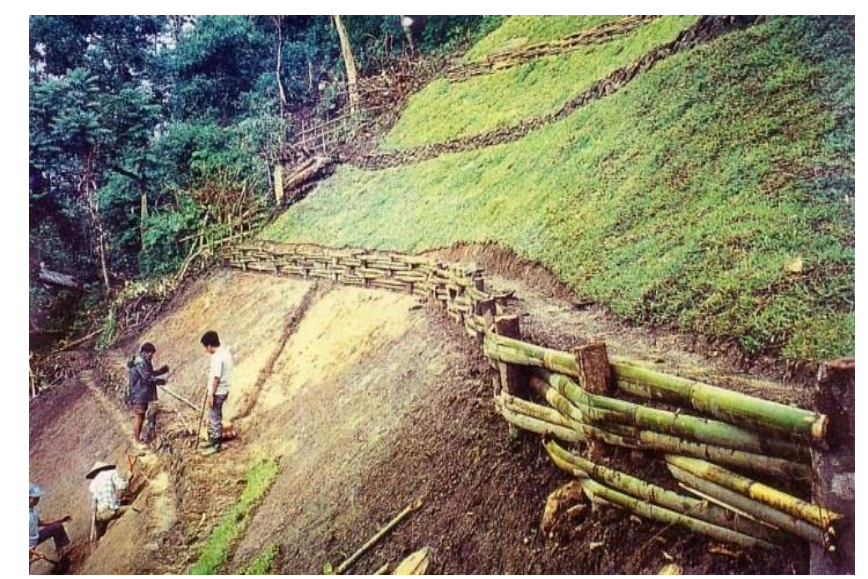

Gambar 8. Bangunan teras bambu pada lahan miring

\section{Teras Karung (Soil Bag Terrace Works)}

Teras karung dapat digunakan sebagai salah satu cara untuk mengurangi erosi dan longsor. Karung yang berisi tanah dan campuran bahan organik, pada awalnya berfungsi sebagai konservasi teknik sipil. Campuran bahan organik yang terdapat dalam karung dapat membantu mempercepat pertumbuhan vegetasi, baik yang sengaja ditanam maupun yang tumbuh secara alami, sehingga lambat laun peranan konservasi teknik sipil digantikan dengan konservasi vegetatif.

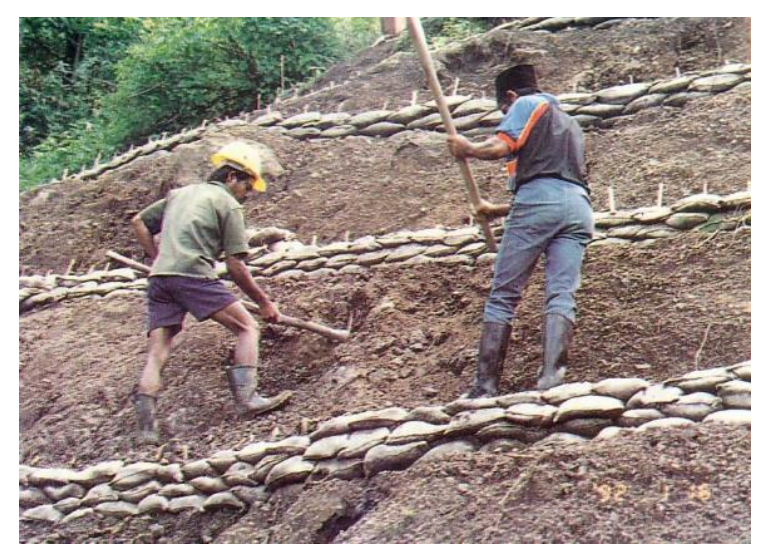

Gambar 9. Bangunan teras karung 


\section{Teras Jerami (Straw Mat Terrace Works)}

Bangunan teknis teras jerami dapat digunakan pada lahan dengan kelerengan curam dengan kondisi sangat kritis. Permukaan tanah ditutup dengan hamparan jerami yang diikat sedemikian rupa pada patok-patok yang ditancapkan dalam tanah. Permukaan tanah dapat terlindungi dari pukulan butirbutir hujan serta memperlambat aliran air dan mencegah erosi dan lonsor. Pada bagian bawah kelompok teras jerami dapat dibuat teras batu (Stone terrace) untuk memperkuat konstruksi dan memperlancar saluran drainase.
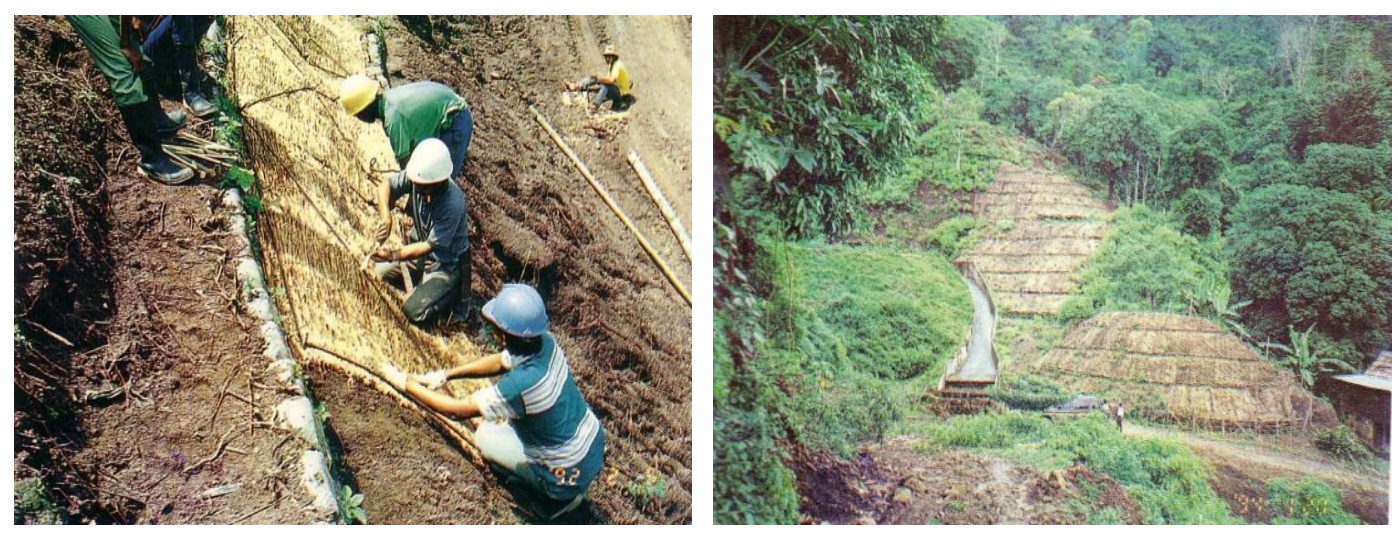

Gambar 10. Pembuatan teras jerami pada lahan miring

\section{Saluran Drainase (Water Channel)}

Untuk mendukung bangunan teknik sipil serta upaya konservasi vegetatif, dapat dibuat saluran yang bermuatan konservasi. Saluran ini terutama berguna pada saat turun hujan lebat, dimana volume air yang melimpah perlu disalurkan pada lokasi penampungan atau pembuangan yang aman. Pada prinsipnya saluran drainase dibagi menjadi 3 macam, yaitu saluran terbuka (parit), saluran tertutup dan gorong-gorong.

Beberapa bentuk saluran drainase adalah (Masaki, 1995):

1. Saluran rumput (Ssd water channel works)

Saluran adalah saluran yang dibuat untuk mengalirkan genangan air ketempat yang aman, dengan penutupan permukaan menggunaan tanaman rumput, yang dimaksudkan untuk mengurangi kejadian erosi pada dinding dan dasar saluran.

2. Saluran dari batu (stone water channel works). 
3. Saluran batu menggunakan material batu untuk menahan tanah dari gerusan air yang mengalir.

4. Saluran karung (soil bag water channel works)

Saluran karung menggunakan karung berisi kerikil untuk menahan tanah dari gerusan air yang mengalir.

5. Saluran tertutup (catchment pipe culvert)

Saluran tertutup mempunyai permukaan yang relatif rata dengan tanah. Untuk keperluan ini digunakan timbunan batu, agar aliran air kebawah menjadi lancar.
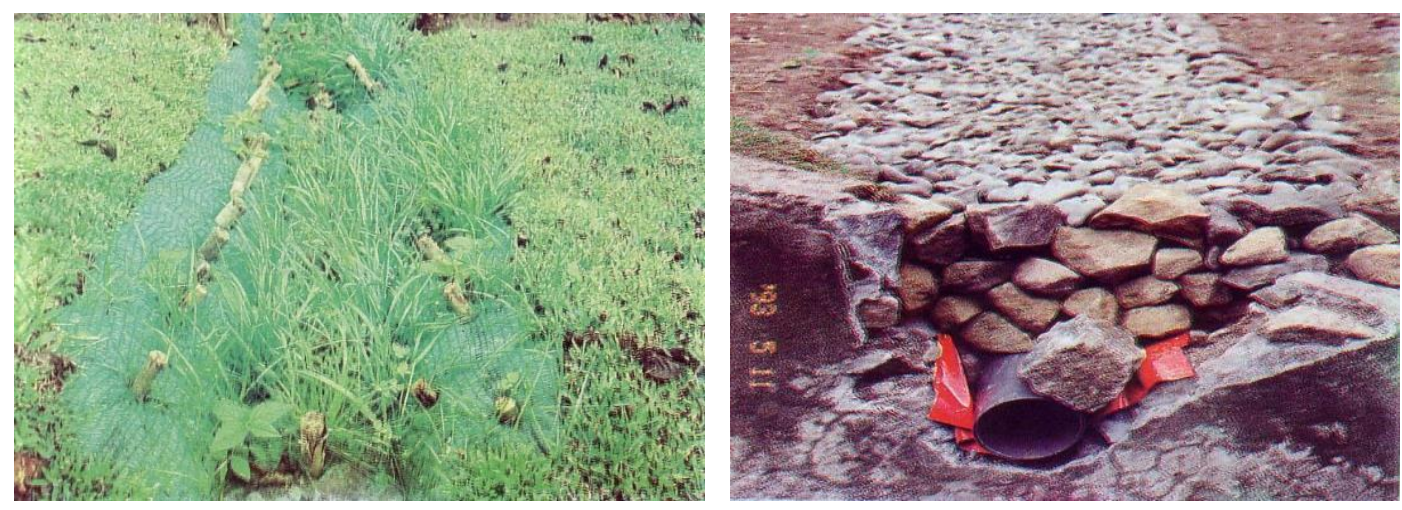

Gambar 11. Saluran terbuka tertutup rumput dan saluran tertutup batu.

6. Gorong-gorong atau knepel
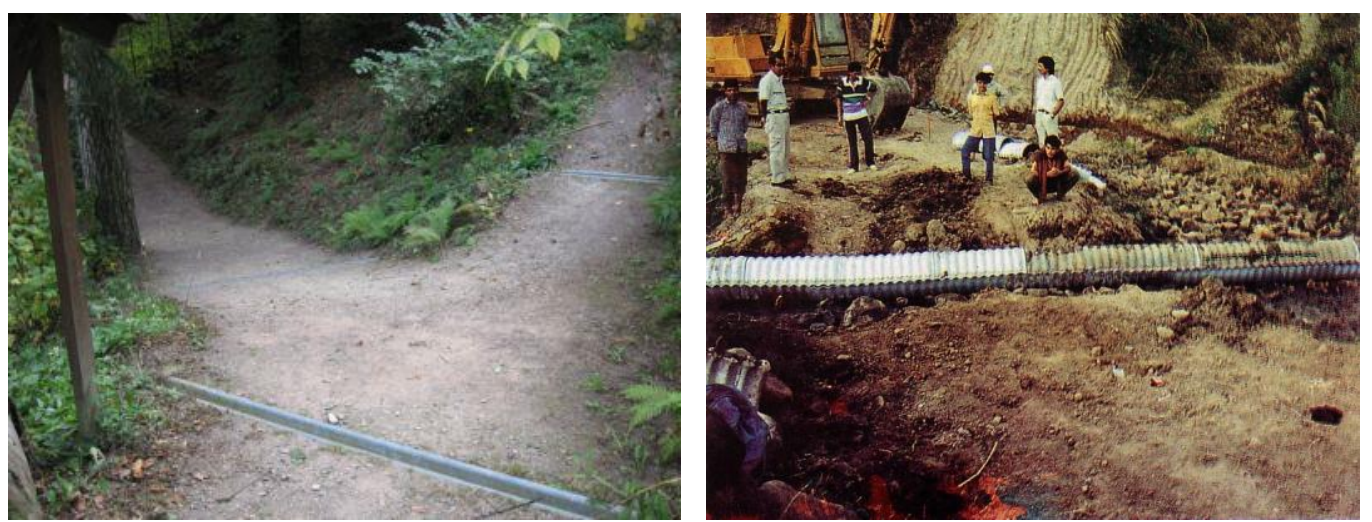

Gambar 12. Saluran terbuka dan tertutup atau gorong-gorong

Gorong-gorong adalah lubang saluran air tertutup yang mengalirkan air dari suatu tempat tergenang menuju ketempat lain yang lebih rendah. Gorong-gorong dapat dibuat dari log kayu yang gerowong atau menggunakan tabung besi. Penimbunan dilakukan menggunakan material jalan (tanah), sehingga tidak nampak dari atas. Saluran air yang berfungsi pula 
untuk penguatan badan jalan disebut knepel. Material knepel biasanya menggunakan kayu keras yang berdiameter kecil, seperti kayu galam (Melaleuca leucadendron), laban (Vitex pubescens), Eucalyptus dan lain-lain.

\section{KESIMPULAN}

Konservasi tanah adalah upaya untuk mempertahankan atau memperbaiki daya guna lahan termasuk kesuburan tanah dengan cara pembuatan bangunan teknik sipil disamping tanaman (vegetatif), agar tidak terjadi kerusakan tanah dan kemunduran daya guna dan produktifitas lahan. Berdasarkan lokasinya, teknik konservasi tanah dan air dilakukan pada lahan berhutan dan tidak berhutan. Konservasi pada lahan tidak berhutan atau lahan kritis dilakukan dengan pendekatan bangunan teknik sipil dan penanaman (cara vegetatif).

Kegiatan konservasi tanah pada lahan kritis menggunakan kombinasi bangunan teknik sipil dan vegetatif terdiri dari beberapa cara, seperti teras tembok (wet masonry),teras batu (stone terrace works), pemasangan kawat bronjong (gabion works), teras kayu (log retaining works), teras kotak (log grib works), teras bambu dan ranting (bamboo and wicker terrace), teras karung (soil bag terrace works) dan teras jerami (straw mat terrace works).Untuk mendukung bangunan teknik sipil serta upaya konservasi vegetatif digunakan saluran drainase yang bermuatan konservasi seperti saluran rumput (sod water channel works), saluran dari batu (stone water channel works), saluran karung (soil bag water channel works), saluran tertutup (catchment pipe culvert), gorong-gorong atau knepel.

\section{DAFTAR PUSTAKA}

[Balitbanghut] Badan Penelitian dan Pengembangan Kehutanan. 2008. Profil Pusat Penelitian dan Pengembangan Hutan dan Konservasi Alam. Balitbanghut, Departemen Kehutanan, Bogor.

BPPHTIBT, 2002. Buletin Teknologi Reboisasi Edisi 2 Tahun 2002. Balai Penelitian dan Pengembangan Hutan Tanaman Indonesia Bagian Timur, Banjarbaru, 2002.

Dephut, 1985. Kumpulan Surat Keputusan Menteri Kehutanan RI Tahun 1980-1985.

Dephut, 1990. Kumpulan Surat Keputusan Menteri Kehutanan RI Tahun 1985-1990.

Dephut, 1996. Hand Book of Indonesian Forestry. Forestry Department of Republic of Indonesia, Jakarta.

Lahjie, A. 2004. Teknik Agroforestry. Universitas Mulawarman Samarinda. ISBN: 979-9276-12-8. 
Masaki, I, 1995. The Watershed Management Technology Development Project. Technical Manual Soil Conservation and Forest Road. Japan International Cooperation Agency.

Mc Kinnon et.al, 2000. Ekologi Kalimantan. Prenhallindo, Jakarta 2000.

Mori T. 2001. Rehabilitation of degraded forest in lowland forest Kutai, East KalimantanIndonesia. In Kobayasi S, Trunbul JW, Toma T, Mori T, Madjid MNNA, editors. Rehabilitation of Degraded TropicalForest Ecosytems. CIFOR-Bogor. Pp. 17-26.

PT Gunung Meranti, 2011. Rencana Karya Usaha Pemanfaatan Hasil Hutan Kayu PT Gunung Meranti Periode 2011-2020. Banjarmasin

Siswomartono, D. 1989. Ensiklopedi Konservasi Sumber Daya. Penerbit Erlangga, Jakartta, 1989.

Wahyudi, 2013.Improving Former Shifted Cultivation Land Using Wetland Cultivation in Kapuas District Central Kalimantan. Journal of Wetlands Environmental Management Vol.1, No.1, December 2013.

Wahyudi, 2014. Sustainable Forest Management Policy in Central Kalimantan, Indonesia. International Journal of Science and Research (IJSR). Vol.3, Issue 4, April 2014. 